\title{
STEROWANIE I KONSTRUKCJE BEZSZCZOTKOWYCH SILNIKÓW PRĄDU STAEEGO
}

\begin{abstract}
W artykule przedstawiono zasadę działania oraz konstrukcję bezszczotkowego silnika prądu stałego. Omówiono także metody sterowania silników BLDC z uwzględnieniem podziału na metody wykorzystujące czujniki służące do określania położenia wirnika oraz metody bezczujnikowe wraz z przykładem realizacji sterowania przy użyciu mikrokontrolerów. Wysoka sprawność i dużej trwałość a także spadające w ostatnich latach ceny elementów elektronicznych oraz sterowników współpracujących z silnikami BLDC spowodowały nową falę zainteresowania napędami tego typu. Konstrukcja silników BLDC nie wymaga zastosowania szczotek, które w tradycyjnych silnikach szczotkowych dostarczają poprzez komutator napięcie do uzwojeń wirnika. Silniki bezszczotkowe cechuje wysoka wydajność, trwałość, a także niezawodność. Stosowanie czujników w układach sterowania silników BLDC zwiększa liczbę połączeń silnika z komutatorem, powodując tym samym zmniejszenie niezawodności układu napędowego. $\mathrm{Z}$ tego powodu często rezygnuje się z bezpośredniego pomiaru położenia i prędkości na rzecz zastosowania bezczujnikowych metod sterownia. Silniki bezszczotkowe prądu stałego mają różnorodne obszary zastosowania, a ze względu na swoją niezawodność oraz możliwość sterowania prędkością są stosowane między innymi w pojazdach elektrycznych, medycynie oraz przemyśle.
\end{abstract}

Słowa kluczowe: silniki BLDC, układ sterowania silnika BLDC, bezczujnikowe metody sterowania, klasyczne metody sterowania

\section{Wstęp}

Silniki bezszczotkowe (BrushLess Direct-Current motors, BLDC motors) stanową grupę silników elektrycznych, w których zamiast mechanicznego komutatora ze szczotkami zastosowano komutator sterowany elektrycznie. W tej konstrukcji cewki są nieruchome, natomiast magnesy są umieszczone na wirniku. Elektroniczny komutator jest zasilany za pomocą prądu stałego. Układ komuta-

\footnotetext{
${ }^{1}$ Autor do korespondencji: Sylwester Czmil, Politechnika Rzeszowska, Katedra Elektrotechniki i Podstaw Informatyki, ul. W. Pola 2, 35-959 Rzeszów, d490@ stud.prz.edu.pl.
} 
tora jest odpowiedzialny kolejno za włączanie i wyłączanie zasilania cewek, których pole magnetyczne powoduje obrót wirnika [1].

Pierwszy model takiego silnika, określony mianem rewolucyjnego ze względu na brak komutatora, powstał w 1962 r. Znalazł on zastosowanie w sterowaniu osiami pozycjonowania robota oraz w lotnictwie, gdzie był używany z uwagi na jego odporność na specyficzne warunki środowiskowe. Ograniczenie zastosowań silników BLDC wynikało wtedy z małej mocy, którą mogły wygenerować.

Przełomowe okazały się lata 80 . XX wieku, kiedy wprowadzono na rynek magnesy trwałe, które $\mathrm{w}$ połączeniu $\mathrm{z}$ wysokonapięciowymi tranzystorami pozwoliły na znaczny wzrost mocy silników bezszczotkowych. Niestety rozwój silników BLDC nie spowodował ich powszechnego wykorzystania ze względu na wysoki koszt elektroniki niezbędnej do sterowania silnikiem. Spadające w ostatnich latach ceny elementów elektronicznych oraz sterowników współpracujących z silnikami BLDC spowodowały nową falę zainteresowania napędami tego typu i zaowocowały pojawieniem się pomysłów na ich wdrożenie w nowoczesnych aplikacjach przemysłowych [2].

\section{Konstrukcje silników}

Podstawowymi elementami wyróżniającymi silniki BLDC jest nieruchomy, uzwojony stojan oraz magnesy trwałe. Jest to konstrukcja odwrotna do silnika szczotkowego, gdzie przeważnie uzwojony jest wirnik. Rolę mechanicznego komutatora pełni układ elektroniczny, który jest odpowiedzialny za generowanie sygnału sterującego w zamkniętej pętli sprzężenia zwrotnego, w zależności od położenia wirnika względem uzwojeń. Do określania położenia wirnika najczęściej używane są czujniki Halla wykrywające określony poziom indukcji magnetycznej w pobliżu czujnika lub enkodery hallotronowe, elektromagnetyczne i optoelektroniczne. Schemat zastępczy silnika BLDC został przedstawiony na rys.1.

Silniki bezszczotkowe prądu stałego są zaliczane do grupy silników synchronicznych ze względu na niezmienną prędkość wirowania wirnika oraz pola magnetycznego, które jest wytwarzane przez uzwojenia stojana. Wirnik silnika bezszczotkowego posiada parzystą liczbę rozmieszczonych naprzemiennie biegunów $\mathrm{N}$ i S. W przypadku trójfazowego silnika BLDC liczba biegunów magnetycznych stojana jest wielokrotnością liczby faz. Liczba biegunów ma wpływ na sposób działania silnika, natomiast liczba faz wpływa bezpośrednio na tętnienia momentu obrotowego. Pole elektromagnetyczne wytworzone na stojanie i wirujące wokół osi silnika powoduje jego ruch [2].

Konstrukcja silników bezszczotkowych nie wymaga zastosowania szczotek, które w konwencjonalnych silnikach prądu stałego dostarczają poprzez komuta- 
tor napięcie do uzwojeń wirnika. Silniki BLDC charakteryzują się wysoką wydajnością oraz znacznie większą trwałością i niezawodnością i mniejszymi wymiarami w stosunku do konwencjonalnych silników prądu stałego, co osiągnięto dzięki eliminacji szczotek oraz wirnika komutatorowego.

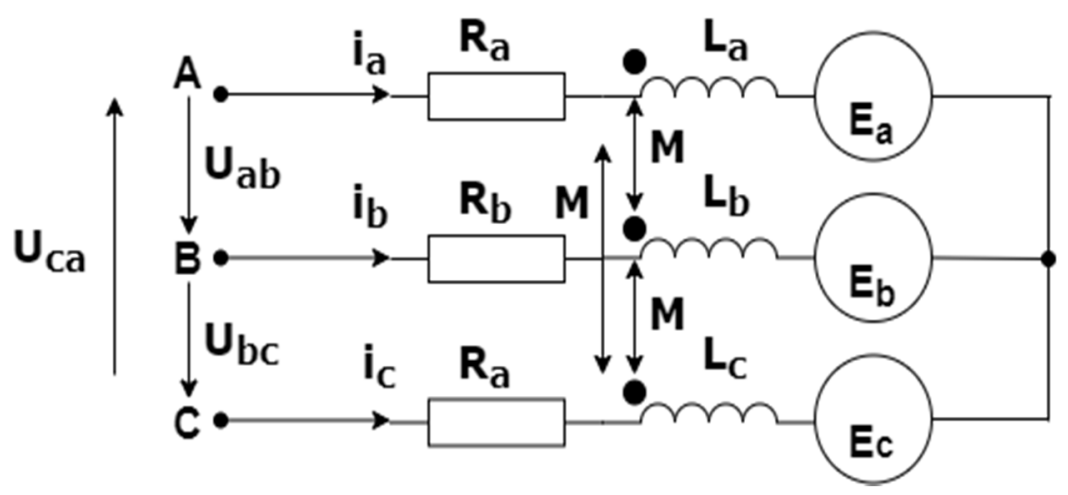

Rys. 1. Schemat zastępczy silnika BLDC, przy czym: R a,b,c - rezystancje faz a, b, c, L a,b,c - indukcyjności własne faz a, b, c, M - indukcyjności międzyfazowe, i a,b,c - prądy fazowe, U ab,bc,ca - napięcia międzyfazowe, E a,b,c - siły elektromotoryczne indukowane w pasmach uzwojeń fazowych.

Fig. 1. Circuit diagram of the BLDC motor, where: R a,b,c - resistances of $a, b, c$ phases, L a,b,c - inductances of a, b, c phases, $\mathrm{M}$ - phase-to-phase inductances, i a,b,c - phase currents, U ab,bc,ca - phase-to-phase voltage, E a,b,c - electromotive forces induced in phase winding bands.

Szczotki stanowią najczęstszą przyczynę awarii oraz są najszybciej zużywającym się elementem mechanicznym silnika, dlatego dzięki ich wykluczeniu jedynym zużywającym się elementem silnika są jego łożyska. Usunięcie ich umożliwia zastosowanie szczelniejszej obudowy, gdyż ciepło może być odprowadzane z cewek bezpośrednio poprzez obudowę [3].

Zaletą silników bezszczotkowych jest możliwość kontroli prędkości obrotowej niezależnie od momentu silnika, natomiast wadą jest wyższy koszt produkcji w stosunku do konwencjonalnych silników, wynikający z konieczności użycia specjalnych sterowników elektronicznych [3]. W porównaniu z konwencjonalnymi silnikami szczotkowymi prądu stałego, silniki BLDC cechuje lepsza charakterystyka momentu obrotowego w funkcji prędkości, wyższą sprawnością energetyczną i dłuższą żywotnością. Mogą także osiągać większą prędkość, są cichsze, a koszty ich konserwacji są niższe. Ponadto stosunek momentu obrotowego do masy silnika BLDC jest także wyższy niż konwencjonalnych silnikach prądu stałego [4]. 
Bezszczotkowe silniki z magnesami trwałymi można podzielić ze względu na kształt napięcia rotacji na silniki prądu stałego (BLDC) oraz silniki prądu przemiennego (BLSM). Kształt ten jest zależny od geometrii obwodu magnetycznego silnika oraz uzwojenia. W silnikach BLDC kształt napięcia rotacji jest trapezoidalny, natomiast stojan silnika może mieć uzwojenia skupione $\mathrm{z}$ jawnymi biegunami lub uzwojenia rozłożone z biegunami utajonymi. Magnesy trwałe o przemiennej biegunowości oraz jednakowej wysokości, umieszczone na wirnikach silników BLDC, gwarantują w przybliżeniu stałą wartość indukcji w szczelnie maszyny w rozpiętości kątowej magnesu. Ukształtowanie magnesów zapewnia trapezoidalny kształt napięcia rotacji w uzwojeniu silnika [3].

Korzystając z modelu obwodowego silnika przy założeniu, że uzwojenie stojana jest trójfazowe, symetryczne i połączone w gwiazdę, magnesy trwałe obejmują ściśle określony kąt $\alpha$, moment zaczepowy oraz straty w żelazie są pomijane, indukcyjności oraz rezystancje uzwojeń są stałe, można wyprowadzić matematyczny model silnika BLDC [5][6]:

$$
\begin{aligned}
& V_{a}=R i_{a}+L \frac{d i_{a}}{d t}+e_{a} \\
& V_{b}=R i_{b}+L \frac{d i_{b}}{d t}+e_{b} \\
& V_{c}=R i_{c}+L \frac{d i_{c}}{d t}+e_{c}
\end{aligned}
$$

gdzie:

$\mathrm{L}$ - samoindukcyjność faz a,b,c,

$\mathrm{R}$ - rezystancja faz a,b,c,

$\mathrm{V}_{\mathrm{a}}, \mathrm{V}_{\mathrm{b}}$ i $\mathrm{V}_{\mathrm{c}}$ - napięcia końcowe,

$\mathrm{i}_{\mathrm{a}}, \mathrm{i}_{\mathrm{b}}$ i $\mathrm{i}_{\mathrm{c}}$ - prąd wejściowy silnika,

$e_{a}, e_{b} i e_{c}-$ siły elektromotoryczne indukowane w pasmach uzwojeń fazowych.

\section{Klasyczne metody sterowania}

Podstawowy układ sterowania silnika BLDC został przedstawiony na rys. 2 . W układzie tym kierunek wirowania i prędkość uzależniona jest od kolejności i częstotliwości łączeń tranzystorów T1 - T6 trójfazowego mostka tranzystorowego. W takim układzie sterowania jednocześnie przewodzi jeden górny i jeden dolny tranzystor mostka. O kolejności włączania tranzystorów i kierunku ruchu wirnika decyduje stan wyjściowy czujników Halla H1-H3. Szerokość sygnału PWM i jego częstotliwość decyduje o prędkości obrotowej silnika i częstotliwości łączeń tranzystorów T1-T6 [7]. 
W klasycznych metodach sterowania każdy tranzystor komutatora elektronicznego przewodzi prąd przez okres $120^{\circ}$ elektrycznych, komutacja faz następuje w równych odstępach $60^{\circ}$, a informacja o aktualnej pozycji wirnika pochodzi $\mathrm{z}$ czujnika położenia wirnika.

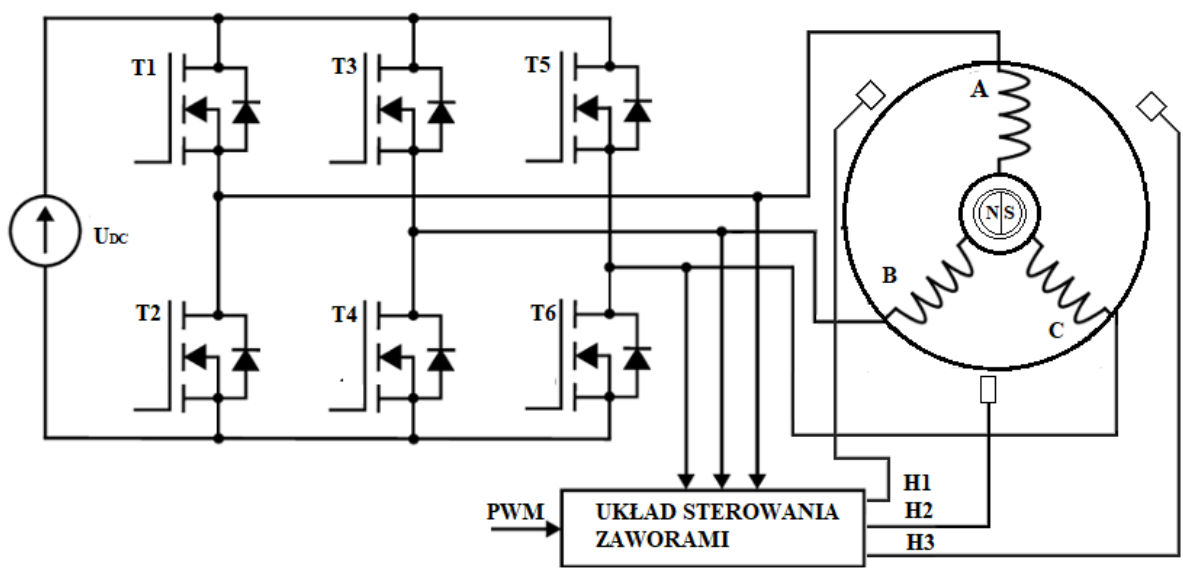

Rys. 2. Podstawowy układ sterowania silnika BLDC

Fig. 2. Classic BLDC motor control system

Można wyróżnić różne kryteria podziału klasycznych metod sterowania silnikami BLDC:

- ze względu na wielkość regulowaną,

- kąt pełnienia funkcji regulacyjnej przez poszczególne zawory komutatora elektronicznego,

- względu na to, która grupa zaworów komutatora elektronicznego realizuje funkcję regulacyjną $\mathrm{w}$ okresie przewodzenia.

Ze względu na wielkość regulowaną strategie sterowania można podzielić na:

- metody prądowe $(C)$ - wielkością regulowaną jest prąd po stronie DC przekształtnika lub prądy fazowe silnika,

- metody napięciowe(V) - wielkością regulowaną jest napięcie silnika.

Ze względu na kąt pełnienia funkcji regulacyjnej przez poszczególne zawory komutatora elektronicznego metody sterowania można podzielić na:

- metody 120 - kąt pełnienia funkcji regulacyjnej przez jeden z tranzystorów wynosi $120^{\circ}$ elektrycznych,

- metody 60 - każdy tranzystor pełni funkcję regulacyjną przez okres $60^{\circ}$ elektrycznych, natomiast przez pozostały okres funkcję regulacyjną pełni zawór z grupy przeciwnej. 
Ze względu na to, która grupa zaworów komutatora elektronicznego realizuje funkcję regulacyjną przez cały okres przewodzenia lub, w której jego części metody sterowania można podzielić na:

- metody Q+ (Q1) - funkcję regulacyjną pełni zawsze tranzystor grupy dodatniej lub jeśli funkcja ta jest realizowana przez pierwsze $60^{\circ}$ okresu przewodzenia każdego tranzystora,

- metody Q- (Q6) - funkcję regulacyjną pełni zawsze tranzystor grupy ujemnej, lub jeśli funkcja ta jest realizowana przez ostatnie $60^{\circ}$ okresu przewodzenia każdego tranzystora.

- metody bipolarne - funkcję regulacyjną pełnią jednocześnie oba przewodzące tranzystory komutatora elektronicznego.

Podział klasycznych metod sterowania silnikami BLDC został przedstawiony na rys. 3.

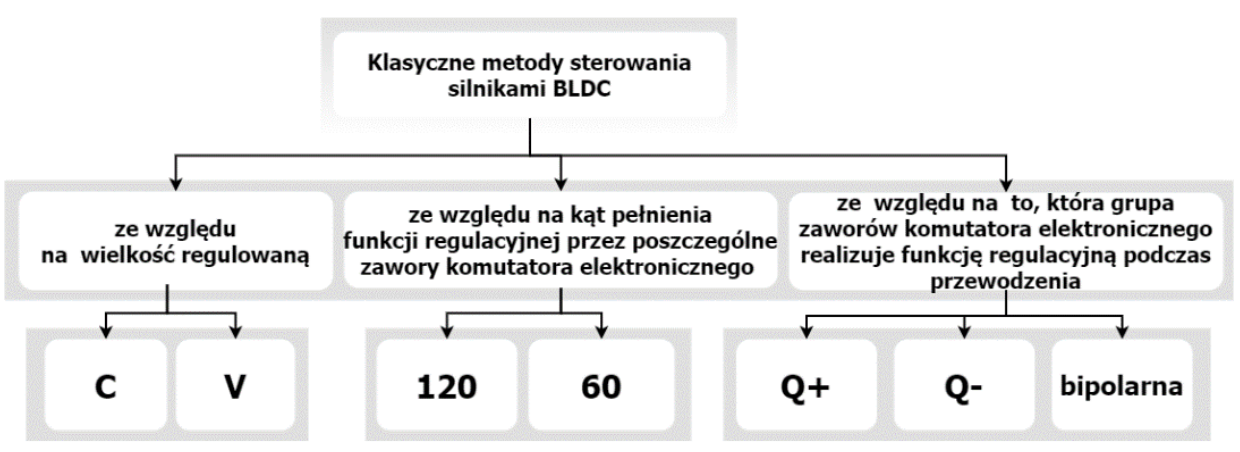

Rys. 3. Podział klasycznych metod sterowania

Fig. 3. Division of classic control methods

Idee sekwencji przełączeń zaworów komutatora elektronicznego dla strategii typu C oraz V są takie same, dlatego zostały omówione na przykładzie prądowych metod sterowania.

W strategiach sterowania C120Q+i C120Q wielkością regulowaną jest prąd silnika. W strategii C120Q+ funkcję regulacyjną pełnią tylko zawory grupy dodatniej, natomiast tranzystory grupy ujemnej pełnią rolę komutatorową. W strategii C120Q- funkcję regulacyjną pełnią wyłącznie zawory grupy ujemnej, a tranzystory grupy dodatniej spełniają rolę komutatorową. Zaletą tych metod jest pełnienie funkcji regulacyjnej tylko przez trzy zawory komutatora, co znacząco upraszcza to realizację układu elektronicznego. Może to jednak powodować nierównomierne wykorzystanie tranzystorów oraz różne częstotliwości ich przełączania.

W strategiach $\mathrm{C} 60 \mathrm{Q}+$ oraz $\mathrm{C} 60 \mathrm{Q}-$ wielkością regulowaną jest również prąd silnika. W strategii C60Q+ tranzystory przez pierwsze $60^{\circ}$ okresu swojego prze- 
wodzenia pełnią funkcję regulacyjną, a przez okres kolejnych $60^{\circ}$ spełniają jedynie rolę komutatorową. Natomiast w strategii C60Q- jest odwrotnie, ponieważ tranzystory przez pierwsze $60^{\circ}$ okresu swojego przewodzenia pełnią jedynie rolę komutatorową, a przez okres kolejnych $60^{\circ}$ spełniają funkcję regulacyjną. Metody te pozwalają na równomierne wykorzystanie wszystkich tranzystorów komutatora, stanowią jednak bardziej skomplikowane układy elektroniczne oraz mają różne częstotliwości przełączeń tranzystorów.

Przy sterowaniu bipolarnym tranzystory przewodzące obu grup pełnią równocześnie funkcje regulacyjną. Sterowanie to pozwala na równomierne obciążenie wszystkich zaworów komutatora elektronicznego oraz jednakowe częstotliwości ich przełączeń. Występują jednak wyższe straty sterowania w porównaniu do metod unipolarnych [8][9].

\section{Bezczujnikowe metody sterowania}

Najczęściej stosowanymi metodami sterowania bezczujnikowego są metody bazujące na napięciach silnika [10]. Pośród nich można wyróżnić:

- metodę bazującą na siłach elektromotorycznych silnika,

- metodę bazującą na trzeciej harmonicznej napięcia,

- metodę bazującą na całce siły elektromotorycznej [11].

Metoda bazująca na siłach elektromotorycznych silnika polega na pomiarze sił elektromotorycznych silnika BLDC. Pomiar siły elektromotorycznej realizowany jest przy użyciu punktu środkowego silnika. Przyjmując, że nie występują komutacyjne spadki napięć, w każdym momencie pracy silnika przewodzą dwie fazy, natomiast faza trzecia pozostaje niezasilona. Napięcie na zaciskach niezasilonej fazy jest równe sile elektromotorycznej, ponieważ nie występuje spadek napięcia na rezystancji oraz indukcyjności uzwojeń. Chwile przełączeń zaworów można wyznaczyć wykrywając chwile przejścia przez zero siły elektromotorycznej i wprowadzając przesunięcie o kąt $30^{\circ}$ [12].

W przypadku sterowania bezczujnikowego, informację o prędkości uzyskuje z rozdzielczością co $60^{\circ}$, analizując czas pomiędzy przełączeniami tranzystorów. Brak ciągłej informacji o prędkości niekorzystnie wpływa na dynamikę układu. Po uwzględnieniu komutacyjnych spadków napięć, okazuje się, że metoda może działać z maksymalnym kątem komutacji wynoszącym $30^{\circ}$, a w praktyce jeszcze mniejszym. Gdy kąt komutacji jest większy niż $30^{\circ}$, przejście przez zero siły elektromotorycznej nie zostanie wykryte, a zawory nie zostaną przełączone w odpowiednim czasie, czego efektem będzie niepoprawna praca silnika lub jego zatrzymanie.

W celu uniknięcia wpływu zakłóceń stosuje się filtry dolnoprzepustowe, które wprowadzają przesunięcie fazowe, będące funkcją częstotliwości, dlatego metoda nie jest zalecana dla silników wysokoobrotowych, gdyż wprowadzone opóźnienie jest zbyt duże. Kolejną wadą metody jest konieczność korzystania 
z punktu neutralnego, który nie jest dostępny w większości komercyjnie sprzedawanych silników [13].

Metoda bazująca na całce siły elektromotorycznej polega na całkowaniu siły elektromotorycznej nieprzewodzącej fazy. Całkowanie rozpoczyna się w chwili przejścia przez zero siły elektromotorycznej. Chwile przełączania zaworów komutatora elektronicznego występują w momencie, gdy wartość całkowanego przebiegu osiągnie określony poziom, który jest zależny od parametrów silnika. Kiedy integrator osiągnie już zadaną wartość, następuje zerowanie, trwające do czasu ustania zjawisk komutacyjnych. Kolejne całkowanie rozpoczyna się od przejścia siły SEM przez zero. Zaletą tej metody jest odporność na szumy, gdyż jest oparta o całkowanie przebiegów. Jej główną wadą jest konieczność doboru odpowiedniego napięcia progowego integratora, możliwość pracy z maksymalnym kątem komutacji nieprzekraczającym $30^{\circ}$ oraz konieczność znajomości potencjału punktu neutralnego silnika.

Metoda sterowania bezczujnikowego, bazująca na napięciach międzyfazowych, pozwala na pracę z kątem komutacji dochodzącym do $60^{\circ}$, co stanowi zaletę tej metody, gdyż możliwa jest praca przy znacznie większym obciążeniu. Kolejną jej zaletą metody prostota implementacji i duża szybkość działania. Chwile przełączania zaworów wyznaczane są z przebiegów napięć międzyfazowych, a zawory przełączane w chwili, gdy napięcie międzyfazowe przechodzi przez zero. Jej wadą jest wpływ spadku napięcia na rezystancji uzwojeń na opóźnienie przełączania zaworów [12].

\section{Kontroler silnika z czujnikami Halla}

Typowa aplikacja sterująca silnikiem BLDC składa się z zasilacza dostarczającego napięcia stałego, interfejsu komunikacyjnego, mikrokontrolera nadzorującego pracę silnika i generującego sygnały sterujące, stopnia końcowego sterownika oraz trójfazowego stopnia wykonawczego [14].

Schemat blokowy kontrolera silnika zbudowanego z użyciem komponentów dyskretnych oraz czujników Halla przedstawiono na rys. 4. Wykorzystuje on mikrokontroler jako element sterujący, stopień mocy bazujący na tranzystorach MOSFET, natomiast moment załączenia zasilania jest wyznaczany przy użyciu czujników Halla.

W silniku BLDC komutator elektroniczny zasila w sposób sekwencyjny uzwojenia stojana, generując tym samym wirujące pole elektromagnetyczne. Wytworzone pole oddziałuje z magnesami stałymi wirnika i wymusza jego obrót. Sterowanie silnikiem 3-fazowym wymaga umieszczenia na stojanie trzech czujników Halla służących do określenia pozycji wirnika względem stojana. Umożliwiają one kontrolerowi zachowanie poprawnej sekwencji oraz właściwego momentu czasowego załączenia zasilania uzwojeń silnika. Czujniki Halla są umieszczone na stojanie co $120^{\circ}$, a na wirniku założony jest pierścień z magnesami trwa- 
łymi. Gdy pole magnetyczne przechodzi przez czujnik Halla, dla danego bieguna jest generowany sygnał. Na podstawie analizy sygnałów otrzymywanych z czujników można uzyskać poprawną sekwencję komutacji można uzyskać na oraz wyznaczyć prędkość obrotową silnika.

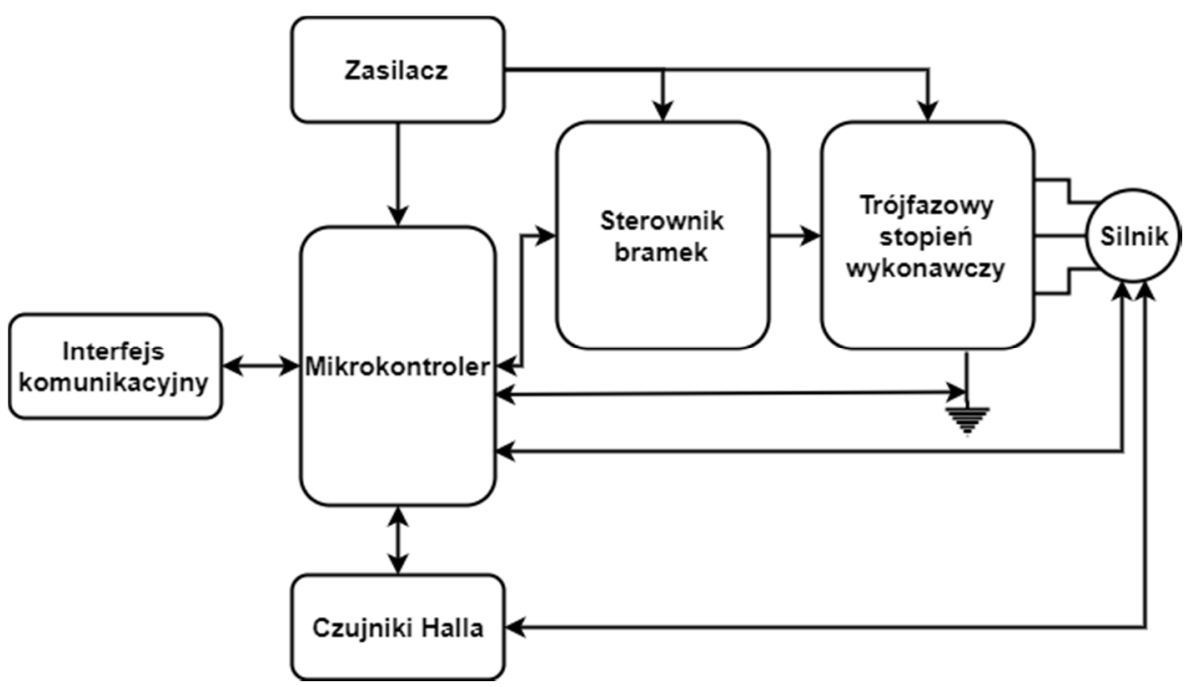

Rys. 4. Schemat blokowy aplikacji kontrolera silnika BLDC z wykorzystaniem elementów dyskretnych.

Fig. 4. Block diagram of the BLDC motor controller application with discrete components.

Na skutek zjawiska indukcji elektromagnetycznej w uzwojeniu silnika generowane jest napięcie, które powoduje przepływ prądu elektrycznego w uzwojeniu i powstanie pola magnetycznego, jednocześnie przeciwdziałając obrotowi wirnika w pożądanym kierunku. Jeśli w silniku prądu stałego utrzymuje się stały strumień magnetyczny i znana jest liczba uzwojeń, to siła elektromotoryczna jest proporcjonalna do rozwijanej prędkości obrotowej silnika [15].

Układ sterowania silnikiem BLDC umożliwiający interakcję z systemem nadrzędnym oraz reagujący w sytuacjach awaryjnych można zrealizować przy użyciu mikrokontrolera, najlepiej wyposażonego w sprzętowy generator PWM. Oferta mikrokontrolerów dostępnych na rynku jest bardzo szeroka. Producenci oferują układy o różnym stopniu złożoności: od prostych układów ogólnego przeznaczenia do specjalizowanych jednostek dedykowanych do zastosowania w sterownikach napędów. Najdłużej obecnymi na rynku układami są mikrokontrolery 8-bitowe, zaliczane do grupy mikrokontrolerów ogólnego przeznaczenia. Kolejną grupę stanowią mikrokontrolery 32-bitowe, które ze względu na relację ceny do możliwości będą zdecydowanie lepszym wyborem. Najbardziej rozbudowanymi układami są mikrokontrolery DSP (ang. Digital Signal Processing), 
które są stosowane w zaawansowanych, bezczujnikowych kontrolerach silników BLDC ze względu na występowanie jednostki wspomagającej przetwarzanie sygnałów [16].

Silniki trójfazowe najczęściej posiadają uzwojenia połączone w trójkąt lub gwiazdę. W literaturze spotykane są również inne, mniej popularne topologie układu zasilania silników PM BLDC, np. o topologii półmostka, topologii Cdump i przekształtnika matrycowego czy o topologii falownika o zredukowanym układzie połączeń, gdzie jedna $\mathrm{z}$ faz dołączona jest do punktu środkowego zasilania [17]. Warto jednak zaznaczyć, że topologia silnika nie powinna mieć wpływu na zasadę działania kontrolera.

Napięcia zasilające poszczególne fazy są załączane przez tranzystory MOS lub IGBT. Mikrokontroler dostarcza sygnał PWM, który określa średnie napięcie i prąd występujące w uzwojeniu oraz prędkość obrotową i moment obrotowy silnika. Czujniki Halla pozwalają natomiast na łatwe ustalenie położenia wirnika. Momentu obrotowego jest wytwarzany przy użyciu pary cewek oraz magnesów stałych. Wykonanie pełnego obrotu przez układ wymaga sześciu kroków komutacji [15].

\section{Sterowanie silnikiem BLDC w kontrolerach bezczujnikowych}

Schemat budowy klasycznej aplikacji sterujących silnikiem BLDC w kontrolerach bezczujnikowych jest bardzo podobny, z tą różnicą, że sterownik mocy został zrealizowany w postaci układu scalonego, natomiast moment załączenia zasilania wyznaczany jest za pomocą metody bezczujnikowej [14].

Dzięki występowaniu zjawiska indukcji elektromagnetycznej, mikrokontroler sterujący napędem pozwala na określenie położenia wirnika względem stojana bez użycia czujników, co umożliwia uproszczenie budowy sterownika, zmniejsza liczbę przewodów oraz podnosi niezawodność napędu. Wadą tego rozwiązania jest fakt, iż zjawisko posiada charakter dynamiczny i jeśli silnik zostanie zatrzymany bądź obracał się będzie z niewielką prędkością, to napięcie indukcji nie wystąpi lub będzie niewielkie i określenie położenia wirnika względem stojana przez mikrokontroler będzie niemożliwe. $\mathrm{Z}$ tego powodu w momencie startu wirnika rezygnuje się często z pętli sprzężenia zwrotnego, a mikrokontroler generuje pewną domyślną sekwencję mającą na celu doprowadzenie do obrócenia się wirnika. Dopiero wtedy pętla sprzężenia zwrotnego jest załączana i sterowanie odbywa się zgodnie z informacjami obieranymi z wirującego silnika.

W celu wyznaczenia położenia wirnika sygnały pochodzące z każdej fazy silnika są filtrowane cyfrowo. Zastosowanie mikrokontrolera DSC pozwala na wyeliminowanie konieczności budowy analogowych filtrów dolnoprzepustowych, pozwalających na wyodrębnienie sygnału zwrotnego SEM oraz współpracujących z nimi komparatorów. Zadanie mikrokontrolera w sterowaniu silnikiem BLDC polega na próbkowaniu trapezoidalnych sygnałów z uzwojeń silnika 
za pomocą przetwornika A/C oraz wyznaczeniu momentu przejścia fazy przez 0 . Następnie filtruje on sygnały powstałe na skutek próbkowania, realizuje funkcję kontrolera PI z zamkniętą pętlą sprzężenia zwrotnego i generuje sekwencję sygnałów sterujących silnikiem BLDC. Na koniec przekazuje dane do systemu nadrzędnego.

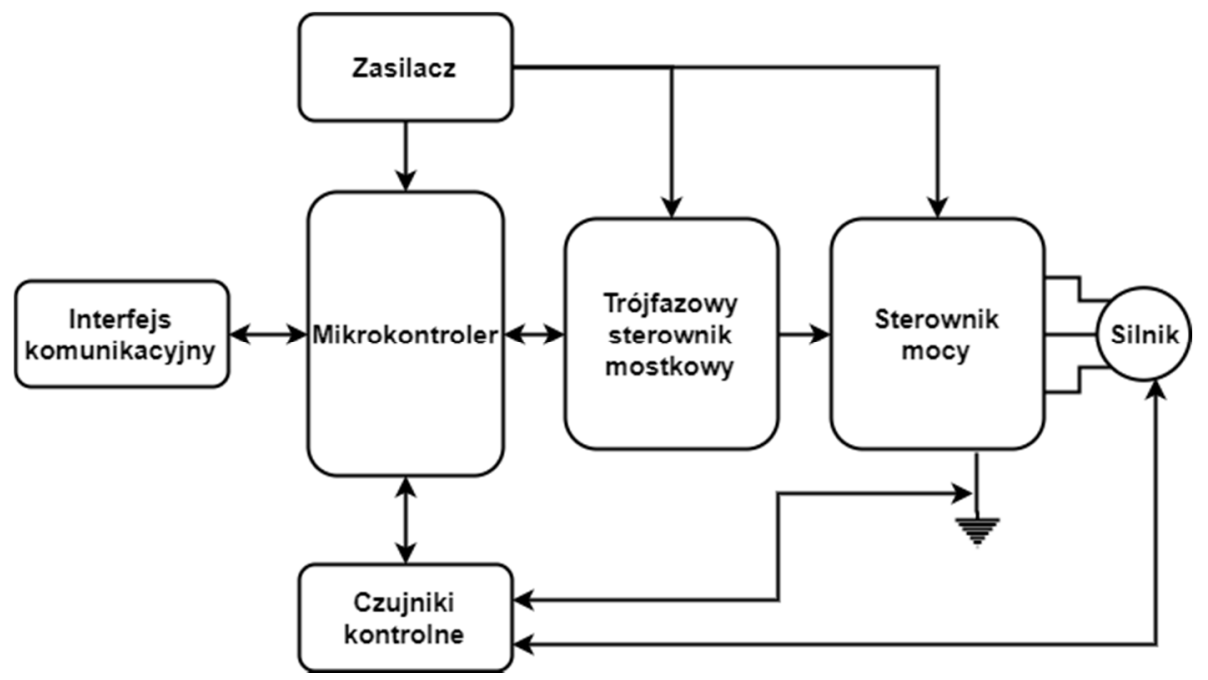

Rys. 4. Schemat blokowy klasycznej aplikacji kontrolera silnika BLDC ze sterownikiem mocy w postaci układu scalonego.

Fig. 4. Block diagram of the BLDC motor controller application with a power controller realized an integrated circuit.

Podczas ruchu silnika generowana jest siła elektromotoryczna, która pełni funkcję informacji zwrotnej, natomiast polaryzacja generowanego napięcia przeciwdziała kierunkowi przepływu prądu przez uzwojenie. Wartość generowanego napięcia zależy od liczby zwojów, prędkości kątowej silnika, a także natężenia strumienia magnetycznego tworzonego przez magnesy trwałe zamontowane na wirniku. Efektywność działania kontrolera silnika jest także zależna od wartości napięcia zasilającego uzwojenia, które powinno być co najmniej równe sumie wartości siły elektromotorycznej oraz napięcia zasilającego uzwojenie. Dla wytworzenia napięcia czy prądu o odpowiedniej wartości stosuje się technikę PWM, natomiast wykrywanie przejścia sygnału SEM przez 0 może być zrealizowane za pomocą porównania napięcia SEM z napięciem wynoszącym połowę napięcia zasilającego silnik lub porównanie napięcia SEM z występującym w punkcie neutralnym [15]. 


\section{Podsumowanie}

Zainteresowanie tematyką bezszczotkowych silników prądu stałego stale rośnie ze względu na różnorodne obszary i możliwości ich zastosowania. Ze względu na swoją niezawodność oraz możliwość sterowania prędkością są stosowane w napędach dysków optycznych, dyskach twardych, gramofonach, pojazdach o napędzie elektrycznym, wentylatorach komputerowych i urządzeniach, w których iskry powstające na szczotkach mogłyby doprowadzić do zaprószenia ognia czy wybuchu, a także modelach zdalnie sterowanych [2]. Coraz częściej są także wykorzystywane do budowy elektronarzędzi akumulatorowych, uzyskując zwiększenie ich wydajności, a także w przemyśle lotniczym oraz medycznym [18]. Wysoka sprawność tych silników sprawia, że nawet przy długotrwałej eksploatacji oszczędzana jest energia.

W niniejszym artykule zdefiniowano pojęcie silnika BLDC $\mathrm{w}$ oparciu o rys historyczny, przedstawiono konstrukcje i zasadę działania bezszczotkowych silników prądu stałego z magnesem trwałym, a następnie zdefiniowano pojęcie klasycznej oraz beczujnikowej strategii sterowania silnikiem BLDC z wyszczególnieniem zalet i wad konkretnych metod. Na końcu omówiono sterowanie silnikiem BLDC przy pomocy klasycznych oraz bezczujnikowych metod sterowania na konkretnym przykładzie z użyciem mikrokontrolera.

\section{Literatura}

[1] Goryca Z., Pakosz, A.: Wolnoobrotowy bezszczotkowy silnik prądu stałego do napędu rogatkowego, Maszyny Elektryczne - Zeszyty Problemowe, nr 2, 2018, s. $15-18$.

[2] Budziłowicz A.: Zastosowanie Silników BLDC (ang.BrushLess Direct-Current motor) we współczesnych napędach elektrycznych i w motoryzacji, Autobusy. Technika, Eksploatacja, Systemy Transportowe, nr 6, 2015, s. 49-52.

[3] Goryca Z.: Bezszczotkowe silniki prądu stałego - konstrukcje i sterowanie, AUTOMATYKA, ELEKTRYKA, ZAKŁÓCENIA, nr 3, 2013, s. 56-63.

[4] Khubalkar S., Jungahare A., Aware M., Das S.: Modeling and control of a permanent-magnet brushless DC motor drive using a fractional order proportional-integral-derivative controller, Turkish Journal of Electrical Engineering \& Computer Sciences, vol. 25, no. 5, 2017, pp. 4223-4241.

[5] Kamal M.M., Mathew L., Chatterji S.: Speed control of brushless DC motor using intelligent controllers, 2014 Students Conference on Engineering and Systems, Allahabad, 2014, pp. 1-5.

[6] Nowak M.: Model matematyczny i symulacyjno-komputerowy układu napędowego reaktora polimeryzacji z modelową wersją silnika BLDC w wykonaniu rurowym, Maszyny Elektryczne - Zeszyty Problemowe, nr 2, 2013, s. 265-270. 
[7] Goryca Z.: Metody sterowania silników BLDC, Prace Naukowe Instytutu Maszyn, Napędów i Pomiarów Elektrycznych Politechniki Wrocławskiej. Studia i Materiały, vol. 66, nr 32, 2012, s. 32-47.

[8] Domoradzki A., Krykowski K: Silniki BLDC - klasyczne metody sterowania, Elektronika Praktyczna, nr 11, 2015, s.71-74.

[9] Zajkowski K., Duer S.: Sterowanie prędkością obrotową silnika bezszczotkowego BLDC, Autobusy. Technika, Eksploatacja, Systemy Transportowe, nr 10, 2013, s. 303-306.

[10] Johnson J.P., Ehsani M., Guzelgunler Y.: Review of sensorless methods for brushless DC, Conference Record of the 1999 IEEE Industry Applications Conference. Thiry Fourth IAS Annual Meeting, 1990, pp. 143-150.

[11] Krykowski K.: Silnik PM BLDC w napędzie elektrycznym, Wydawnictwo Politechniki Śląskiej, Gliwice, 2011.

[12] Makieła D., Tomaszczyk T.: Bezczujnikowe sterowanie silnika wysokoobrotowego PM BLDC przy pomocy metody bazującej na napięciach międzyfazowych, nr 4, 2014, s.92-96.

[13] Makieła D.: Bezczujnikowe sterowanie wysokoobrotowego silnika PM BLDC, Elektryka, nr 2-3, 2013, s.109-118.

[14] Brushless DC Motor, Infineon Technology, dostępny w Internecie: https://www.infineon.com/cms/en/applications/solutions/motor-control-and-drives/brushless-dcmotor/?redirId=100355, [dostęp: 07.01.2020r.].

[15]Bogusz J.: Podstawy sterowania silnikiem BLDC, dostępny w Internecie: http://www.easy-soft.net.pl/artykuly/podzespoly/podstawy-sterowania-silnikiembldc, [dostęp: 07.01.2020r.].

[16] Kuciński M., Jarzębowicz L. Analiza właściwości mikrokontrolerów do zastosowania w układach sterowania napędami elektrycznymi. Zeszyty Naukowe Wydziału Elektrotechniki Automatyki PG, nr 31, 2012.

[17] Skóra M. Analiza wpływu wybranych uszkodzeń na pracę napędu z silnikiem PM BLDC w układzie zasilania z zewnętrznym regulatorem napięcia. Badania Symulacyjne. Prace Naukowe Instytutu Maszyn, Napędów i Pomiarów Elektrycznych Politechniki Wrocławskiej vol. 71, no. 35, 2015.

[18] Pillay P., Krishnan R.: Modeling, simulation and analysis of permanent magnet motor drives, part II: The brushless DC motor drive, IEEE Transactions on Industry Applications, nr 25, 1989, s. 274-279.

\section{CONTROL AND CONSTRUCTIONS OF BRUSHLESS DIRECT- CURRENT MOTORS}

\section{S u m m a r y}

The article presents the working principles and construction of a brushless DC motor. The BLDC motor control methods were discussed, including the division into methods using sensors for determining the rotor position and sensorless methods with an example of implementing BLDC motor control using microcontrollers. High efficiency and high durability as well as falling prices 
of electronic components and controllers cooperating with BLDC motors in recent years have caused a growing interest in this type of motors. The design of BLDC motors does not require the use of brushes, which in traditional brush motors supply voltage through the commutator to the rotor windings. Brushless motors are characterized by high efficiency, durability and reliability. The use of sensors in BLDC motor control systems increases the number of motor and commutator connections, thereby reducing the reliability of the drive system. For this reason, direct position and speed measurements are often abandoned for the use of sensorless control methods. DC brushless motors have various application areas, and due to their reliability and the ability to control speed, they are used, among others, in electric vehicles, medicine and industry.

Keywords: BLDC motors, BLDC motor control system, sensorless control methods, classic motor control methods

DOI: $10.7862 /$ re. 2020.2

Przestano do redakcji: styczeń $2020 \mathrm{r}$.

Przyjęto do druku: luty $2021 \mathrm{r}$. 